\title{
Undocumented Late 18th- to Early 19th-Century Volcanic Eruptions in the Southwest Rift Zone of Kilauea Volcano, Hawai'i
}

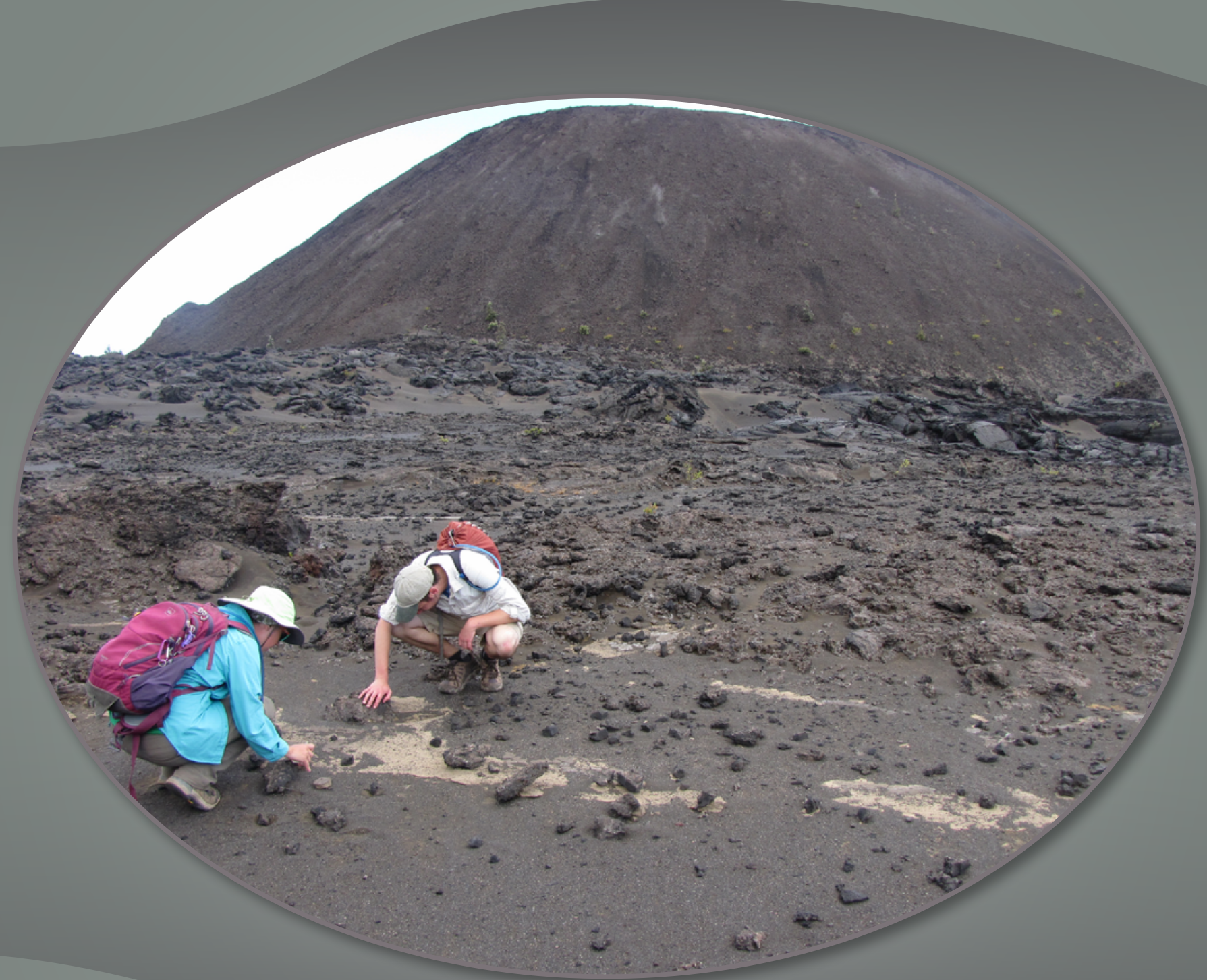

Scientific Investigations Report 2019-5010

U.S. Department of the Interior

U.S. Geological Survey 
Cover. Photograph of geologists at Kamakai'a Waena cone, with Kamakai'a basaltic andesite flow overlying 1790 accretionary-lapilli-bearing ash, Kilauea Volcano, Island of Hawai'i. (Photograph by Richard Hazlett.) 


\section{Undocumented Late 18th- to Early 19th-Century Volcanic Eruptions in the Southwest Rift Zone of Kïlauea Volcano, Hawai'i}

By Richard W. Hazlett, Tim R. Orr, and Steve P. Lundblad

Scientific Investigations Report 2019-5010 


\title{
U.S. Department of the Interior \\ DAVID BERNHARDT, Acting Secretary
}

\author{
U.S. Geological Survey \\ James F. Reilly II, Director
}

U.S. Geological Survey, Reston, Virginia: 2019

For more information on the USGS-the Federal source for science about the Earth, its natural and living resources, natural hazards, and the environment-visit https://www.usgs.gov/ or call 1-888-ASK-USGS (1-888-275-8747).

For an overview of USGS information products, including maps, imagery, and publications, visit https://store.usgs.gov.

Any use of trade, firm, or product names is for descriptive purposes only and does not imply endorsement by the U.S. Government.

Although this information product, for the most part, is in the public domain, it also may contain copyrighted materials as noted in the text. Permission to reproduce copyrighted items must be secured from the copyright owner.

Suggested citation:

Hazlett, R.W., Orr, T.R., and Lundblad, S.P., 2019, Undocumented late 18th- to early 19th-century volcanic eruptions in the Southwest Rift Zone of Kīlauea Volcano, Hawai'i: U.S. Geological Survey Scientific Investigations Report 2019-5010, 13 p., https://doi.org/10.3133/sir20195010.

ISSN 2328-0328 (online) 


\section{Acknowledgments}

The authors are grateful for the instructive conversations and insights provided by U.S. Geological Survey (USGS) Hawaiian Volcano Observatory (HVO) researchers Ingrid Johansen, James Kauahikaua, Paul Okubo, Donald Swanson, and Frank Trusdell. HVO intern Roger Medina Hernandez, University of Hawai'i contractor Lil DeSmither, and Pomona College students Ann Fulton and Benjamin Murphy, each gave field support. We also acknowledge helpful communications with Michael Poland, Wes Thelen, and Carl Thornber at the USGS Cascade Volcano Observatory and Matt Patrick at HVO. In addition, we thank Tina Neal (HVO), Julie Donnely Nolan (USGS), and Michael Garcia (University of Hawai i at Mānoa) for comments that helped improve and clarify the manuscript. J. Michael Rhodes (Department of Geosciences, University of Massachusetts, Amherst) provided the x-ray fluorescence analyses shown in table 2. Wagner Petrographic, Lindon, Utah, prepared thin sections, and Beta Analytic Inc., Miami, Florida, provided radiocarbon data in table 1. 


\section{Contents}

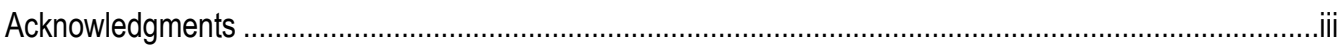

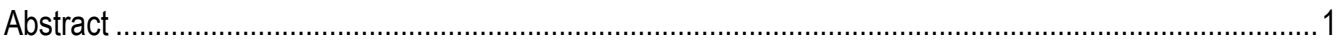

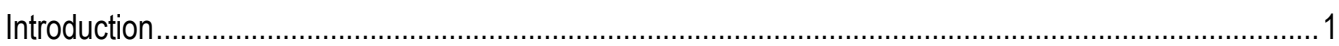

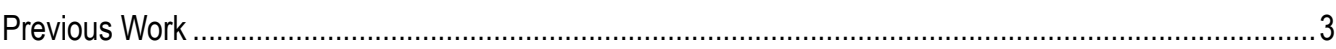

Reevaluating the Ages to Document Late 18th- to Early 19th-Century Eruptions in the Southwest

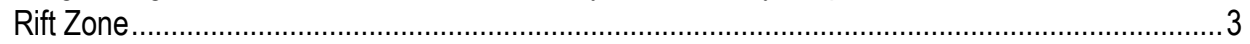

Significance of Late 18th- to Early 19th-Century Eruptions in the Southwest Rift Zone...........................8

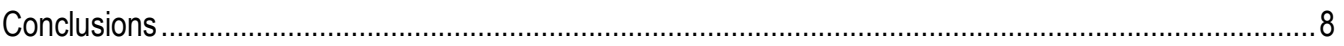

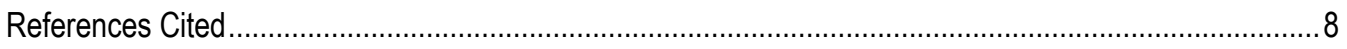

Appendix-Overview of Field Studies and Changes in the Mapping of Kīlauea's Southwest Rift Zone .... 11

\section{Figures}

1. Map of post-1790 lava flows in the Southwest Rift Zone of Kīlauea Volcano, Island of Hawai'i.. 2

2. Photograph showing trench beneath contact of the Kamakai'a Lava Flow of Kīlauea Volcano, Island of Hawai'i.

3. Photograph showing stratigraphic exposures in the wall of a wind-eroded cave beneath the upper Keala'alea flow of Kìlauea Volcano, Island of Hawai'i

4. Photomicrographs of thin-sectioned samples from the lower Keala'alea and Black Cone lava flows and the Kamakai'a Lava Flow of Kĩlauea Volcano, Island of Hawai'i

5. Geologic map of the central and eastern Kamakai'a Hills of Kïlauea Volcano, Island of Hawaíi ............7

6. Significant changes in the published mapping and names of young Southwest Rift Zone lava flows of Kïlauea Volcano, Island of Hawai'i, examined in this study, from early 20th century to present.

\section{Tables}

1. Conventional radiocarbon age and eruption occurrence interval for the lower Keala'alea flow and for pāhoehoe underlying the Black Cone flow of Kĩlauea Volcano, Island of Hawai'i .

2. Selected geochemical analyses of lava flows examined for this study in the Southwest Rift Zone of Kïlauea Volcano, Island of Hawai'i. 


\section{Conversion Factors}

International System of Units to U.S. customary units

\begin{tabular}{llc}
\hline \multicolumn{1}{c}{ Multiply } & By & To obtain \\
\hline centimeter $(\mathrm{cm})$ & \multicolumn{2}{c}{ Length } \\
millimeter (mm) & 0.3937 & inch (in.) \\
meter $(\mathrm{m})$ & 0.03937 & inch (in.) \\
kilometer $(\mathrm{km})$ & 3.281 & foot (ft) \\
\hline \multicolumn{2}{c}{ Area } & mile (mi) \\
\hline hectare (ha) & 0.6214 & acre \\
\hline
\end{tabular}

\section{Abbreviations}

$\begin{array}{ll}\text { AMS } & \text { accelerator mass spectrometry } \\ { }^{14} \mathrm{C} & \text { carbon-14 } \\ \text { USGS } & \text { U.S. Geological Survey }\end{array}$

\section{Datum}

Horizontal coordinate information is referenced to the World Geodetic System 1984 (WGS 1984). 



\title{
Undocumented Late 18th- to Early 19th-Century Volcanic Eruptions in the Southwest Rift Zone of Kïlauea Volcano, Hawai'i
}

\author{
Richard W. Hazlett, ${ }^{1}$ Tim R. Orr, ${ }^{2}$ and Steven P. Lundblad ${ }^{3}$
}

\begin{abstract}
The historical record of volcanic activity at Kîlauea Volcano on the Island of Hawai' $i$ begins with the phreatomagmatic blasts of 1790 . Three decades later, in 1823, the first party of non-Hawaiian visitors, organized by the English Reverend William Ellis, reached Kīlauea's summit. A detailed narrative by Ellis includes an account of an eruption in Kîlauea's Southwest Rift Zone that occurred shortly before his visit. In the absence of other source materials, the interval between the eruptions of 1790 and 1823 has been overlooked by geologists working at Kîlauea, with the presumption that little if anything took place volcanically outside of the summit caldera during that time. Careful stratigraphic observations combined with radiocarbon dating demonstrate that during these years a set of Southwest Rift Zone eruptions took place, including two that were long-lasting (weeks to months). Inclusion of these events gives a more complete historical (post-1790) record for Kīlauea and a better understanding of its eruptive behavior.
\end{abstract}

\section{Introduction}

Kîlauea, an active volcano on the Island of Hawai' $i$, features two prominent rift zones, radiating from a summit caldera overlying a magma reservoir (fig. 1). The East Rift Zone, which is 130 kilometers $(\mathrm{km})$ long, is the longer and more active of Killauea's two rift zones, stretching all the way to the base of the shield at a depth of 4.5-5 km below sea level (Clague and others, 1994). The 40-km-long Southwest Rift Zone is wider than the East Rift Zone along most of its length (3-4 km compared to 2-3 km). Unlike the East Rift Zone, with about 60 percent of its length submerged, most of the Southwest Rift Zone is subaerial and does not extend to the

\footnotetext{
${ }^{1}$ Professor emeritus, Pomona College Department of Geology, Claremont, California. Adjunct faculty member, University of Hawai'i at Hilo, Department of Geology. Associate, Department of Interior.

${ }^{2}$ U.S. Geological Survey.

${ }^{3}$ University of Hawai'i at Hilo, Department of Geology.
}

base of the shield, but rather terminates high on the western shield flank only a few kilometers offshore. The trend of the Southwest Rift Zone bends approximately $30^{\circ}$ from southwest to south-southwest near $\mathrm{Pu}$ 'ukou, a prominent knob in the Kealaalea Hills about two-thirds of the way down the length of the rift zone (fig. 1). The bend in the rift zone probably relates to the complex interaction between Mauna Loa and Kîlauea Volcanoes (Lipman and others, 2006).

Following Kīlauea's catastrophic explosive eruption in 1790 , lava fountaining and lava lake activity began slowly filling Kīlauea's caldera, and effusive eruptions may have taken place along the East Rift Zone. These changes apparently reflect an increase in magma supply rate (Swanson and others, 2014). However, except for sparse suggestive data provided by Holcomb (1987), the Southwest Rift Zone has generally been believed to show no evidence of this change, not erupting lava until 1823 (for example, Wright and Takahashi, 1989; Simkin and Siebert, 1994; Wright and Klein, 2014). The purpose of this report is to provide new information that shows that several volcanic eruptions took place in the Southwest Rift Zone during the late 18th- to early 19th-century thereby correcting this previous view and demonstrating that the Southwest Rift Zone erupted a large volume of lava between 1790 and 1823. Early response to the increased magma supply indicates that the Southwest Rift Zone remained well-connected to the summit magma reservoir throughout early historical time, and this should not be overlooked despite the prevalence of eruptive activity in the East Rift Zone in recent decades.

The geographic place names and feature names used in this document are mostly those approved by the U.S. Board on Geographic Names (https://geonames.usgs.gov/domestic/ index.html). In some cases, we use historical names not listed in the Geographic Names Information System database. Where appropriate, these names use lower case common nouns to indicate their lack of formal geographical recognition. Of special note is the Black Cone lava flow, which we discuss below. The vent structure for this flow is identified formally as Red Cones in the Geographic Names Information System database. However, it is plainly labeled as Black Cone on the 1907 Hawaii Territory Survey map of Kapapala by Baldwin and Wright (1907), with an older vent structure about 500 meters $(\mathrm{m})$ north labeled as 


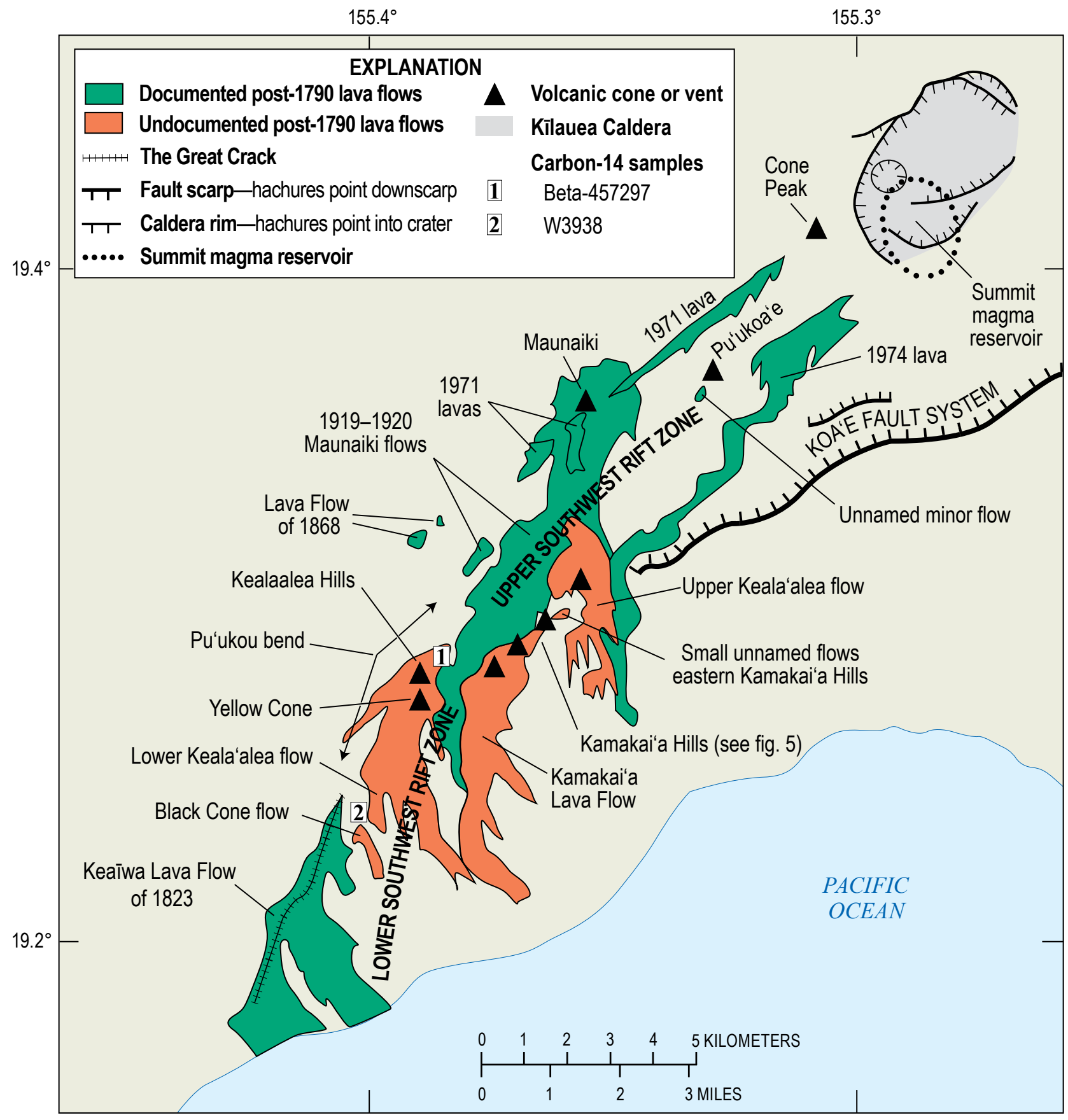

Figure 1. Map of post-1790 lava flows in the Southwest Rift Zone of Kīlauea Volcano, Island of Hawai'i, including major vents and related tectonic features. Locations of flows simplified from Wolfe and Morris (1996). The index map shows the general relations of the Southwest Rift Zone (SWRZ) and East Rift Zone (ERZ) to Kīlauea's caldera. The Kamakai'a Hills are a group of cinder and spatter cones with three main cones-Kamakai'a, Kamakai'a Waena, and Kamakai'a Uka (see fig. 5).

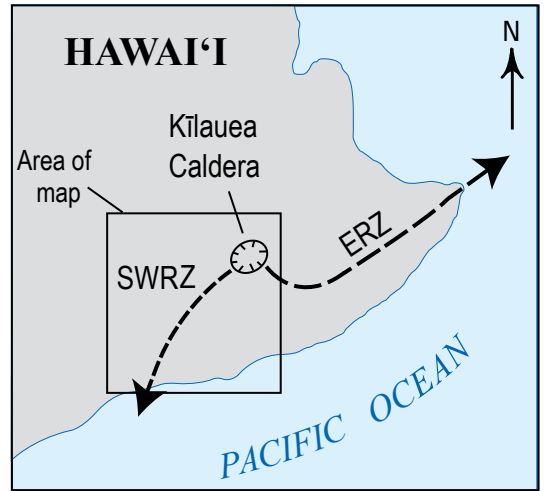


Red Cone. In the field, Black Cone is, indeed, dark in color, whereas the much older Red Cone is reddish in color. We therefore use the informal term "Black Cone lava flow" to be consistent with mapping by Baldwin and Wright (1907), which is a better match with conditions on the ground.

\section{Previous Work}

In 1823, the English Reverend William Ellis and his party, searching for sites suitable for establishing church missions, were the first known non-Hawaiians to visit Kîlauea Volcano. Ellis describes visiting the vent area of a recently erupted lava flow in late July 1823 (Ellis, 1825). Figure 1 shows the extent of this flow, now known formally as the Keaiwa Lava Flow of 1823.

Following Ellis, until the present study, geological publications that focus on the Southwest Rift Zone show considerable uncertainty and, in some cases, conflicting assumptions about the ages of other lava flows along the rift zone. Arguments have even arisen about the true dates of historically erupted flows (for example, Hitchcock, 1911, versus Stearns, 1926). The appendix at the end of this report provides more information about past Southwest Rift Zone studies, illustrating the slow evolution of geological understanding and naming of features in this region.

Holcomb (1987) was the first geologist to undertake detailed geological mapping throughout the entire Southwest Rift Zone, using radiocarbon dating and paleomagnetic analyses to date lava flows of unknown age. He based his work partly on the earlier geological mapping of Walker (1969) in the central Southwest Rift Zone. In addition to those related to documented historical eruptions, Holcomb's data indicate that one flow immediately south of the Maunaiki vent erupted sometime in the early 19th century. All other flows were considered by Holcomb (1987) to be prehistoric - that is, pre-1790 in age. Later geological mapping compiled by Wolfe and Morris (1996) incorporated Holcomb's work. Neal and Lockwood (2003) then provided greater detail of flow contacts and stratigraphy where the upper Southwest Rift Zone intersects Kīlauea’s caldera.

\section{Reevaluating the Ages to Document Late 18th- to Early 19th-Century Eruptions in the Southwest Rift Zone}

We studied stratigraphy, collected and analyzed rock samples, and undertook radiocarbon dating to reexamine the ages of four large, young-looking Southwest Rift Zone lava flows mapped by Holcomb (1987). To the extent possible, we used place names used by Holcomb, adding the convention of Hawaiian diacritical marks and making changes where necessary. Figure 1 provides map outlines of our units, including the upper and lower Keala'alea lava flows, the Kamakai'a Lava Flow, and the Black Cone lava flow. We consider these flows as candidates for eruption following the 1790 phreatomagmatic eruption, very likely in the 1790-1823 timeframe, and certainly sometime in the interval from 1790-1868, after which the observational record begins to grow robust and lava surfaces show significantly less evidence of oxidation, glass loss, and weathering.

The 1790 accretionary-lapilli-bearing ash, unit I of Swanson and Houghton (2018), is the sole dated stratigraphic marker unit exposed in the Southwest Rift Zone. This ash is widespread in the upper segment of the rift zone and in the Kamakai'a Hills, but it cannot be traced downslope from this region, due to erosion and depositional limit. We excavated and examined cavities beneath the contacts of both the upper Keala'alea flow and the Kamakai'a Lava Flow and clearly observed that these flows overlie unit I. The ash is locally baked but otherwise mostly undisturbed beneath these flows owing to an intervening layer of wind-drift ash from summit eruptions, in places reaching 30 centimeters $(\mathrm{cm})$ thickness (figs. 2 and 3).

Only the lower Keala'alea flow yielded charcoal for radiocarbon work, which we collected from beneath the edge of the flow and from tree molds near the upslope terminus of the flow's eruptive fissure. The charcoal was clearly formed during flow emplacement. In some places, mostly decayed tree trunks and branches associated with tree molds were still present on the surface of the flow, testifying to the relatively young age of this lava. Other seemingly young flows featured little if any underlying soil, owing to too short a period for weathering and sedimentary accumulation to take place, although one- the Black Cone flow (fig. 1) — covers pockets of paleosol as much as a few tens of centimeters thick. However, we identified no charcoal in these pockets. Other than close to its source, the Black Cone flow is also almost entirely in the form of ' $a$ ' $\bar{a}$, which does not favor charcoal preservation (Lockwood and Lipman, 1980).

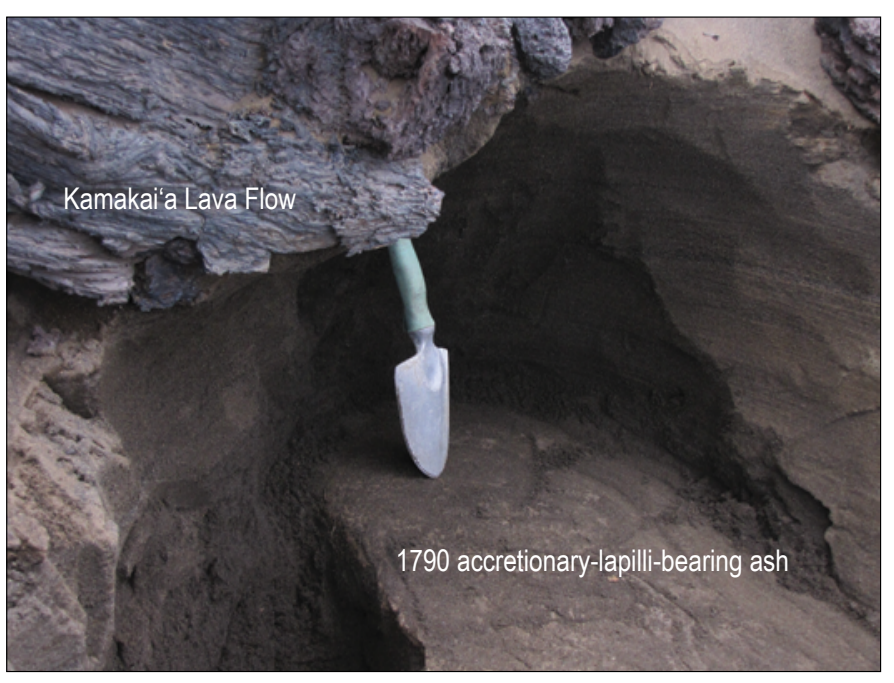

Figure 2. Photograph showing trench beneath contact of the Kamakai'a Lava Flow of Killauea Volcano, Island of Hawaili, near the southeastern base of Kamakai'a Waena, the largest cone built during eruption of the flow. Accretionary-lapilli-bearing ash from 1790 (unit I of Swanson and Houghton, 2018) dips beneath the lava. (Photograph by Richard Hazlett.) 


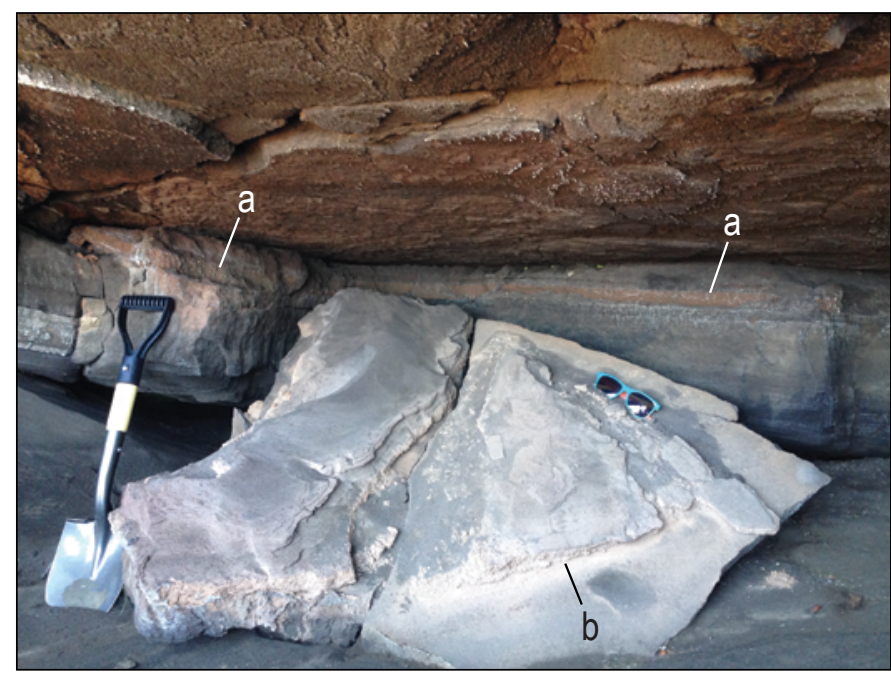

Figure 3. Photograph showing stratigraphic exposures in the wall of a wind-eroded cave beneath the upper Keala'alea flow of Kïlauea Volcano, Island of Hawaili, which forms the ceiling. Intact, hardened 1790 accretionary-lapilli-bearing ash crops out in the wall (points labeled a), and in the locally detached block on the cave floor (point labeled b), clearly underlying upper Keala'alea lava. This locality is indicated on figure 5. (Photograph by Richard Hazlett.)

Accelerator mass spectrometry (AMS) radiocarbon analysis of a sample of the charcoal beneath the lower Keala'alea flow, corrected for total isotopic fractionation effects, returned a conventional carbon-14 $\left({ }^{14} \mathrm{C}\right)$ age of $170 \pm 30$ years before present (table 1). Calibration of the data from the sample using the 2013 INTCAL program and the INTCAL13 database (Reimer and others, 2013), following the approach of Talma and Vogel (1993), yields a 55 percent chance (within two standard deviations, $2 \sigma$ ) of the lower Keala'alea eruption occurring between 1722 and 1817 (table 1). The surface of the lower Keala'alea flow, including the inside of tree molds, lacks deposits of the wind-drift ash from summit eruptions seen on the surface of older surrounding flows and the 1790 accretionary-lapilli-bearing ash (unit I) farther upslope. This indicates that the lower Keala'alea flow is younger than 1790. The eruption must have lasted for weeks, or even months, based on the development of features only observed to form during long-duration extrusive events (for example, Patrick and Orr, 2011). These features include two perched lava ponds with well-established levees that feed a chain of rootless lava shields, including Pu'ukou. Holcomb (1987) also identifies the lower Keala'alea flow as being a sustained eruption.

The relation between the lower and upper Keala'alea flows can be established petrographically and structurally. Thin-section study of these and other central Southwest Rift Zone lavas reveals that samples collected from different flows characteristically show distinctive appearances under the polarizing microscope, even when hand samples appear to be uniformly similar. Key differences include phenocryst composition, texture, abundance, and arrangement (fig. 4). Although groundmass features such as microlite abundances, alignments, and composition may be regarded as secondary products of rapid cooling, we also noted useful distinguishing aspects based on observations at that scale. Samples from the upper and lower Keala'alea flows are virtually identical petrographically where the contacts of these lavas are closest in the field. The lower Keala'alea vents align well with those of the upper Keala'alea flow by straightforward extension along the rift zone. Also, the upper Keala'alea eruption lasted for a long time, producing a well-established lava tube system from which hornitos developed (Stearns and others, 1930). Geochemical data also establish a clear link between the upper and lower Keala'alea flows through nearly identical major- and trace-element concentrations (table 2). Finally, the upper and lower Keala'alea flows have the same general color, a product of surface weathering, in satellite imagery. The combined evidence indicates almost certainly that both the lower and upper Keala'alea flows are products of the same eruption. If this is the case, then the age of the Keala'alea flows can be constrained, since the upper Keala'alea flow was emplaced on top of 1790 accretionary-lapillibearing ash. The lower Keala'alea flow is overlain by the Keaiwa Lava Flow of 1823, placing an absolute upper bound on its age. Thus, the lower and upper Keala'alea flows were most likely erupted sometime between 1790 and 1823.

The eruption of Kamakai'a Lava Flow covered an area similar in size to the combined Keala'alea flows, and must have also persisted for weeks or months, building the Kamakai'a and Kamakai'a Waena cones and a smaller unnamed spatter cone immediately east of the Kamakai'a Waena cone. The eruption also built two rootless shield complexes along lava tube systems extending southwest from the eruptive fissure that produced the Kamakai'a cone (fig. 5). The Kamakai'a Lava Flow is petrographically and chemically distinctive from Keala'alea lava (table 2, fig. 4) and erupted later - it erupted along a different strand of the rift zone and plainly overlies lower Keala'alea lava where it comes into contact in two locations.

The Black Cone flow is overlain by, and therefore older than, the Keaiwa Lava Flow of 1823. However, it is geographically separated from both the Keala'alea flows and the slightly younger Kamakai'a Lava Flow, so cannot be further constrained in age from stratigraphic contacts. The 1790 accretionary-lapilli-bearing ash (unit I) is not preserved in this part of the rift zone. However, Black Cone lava overlies an unnamed pāhoehoe flow, which includes numerous tree molds. Holcomb $(1981,1987)$ collected charcoal from beneath this flow for which a conventional ${ }^{14} \mathrm{C}$ age of $210 \pm 60$ years was determined (table 1; Holcomb, 1981; Rubin and others, 1987). More broadly, calibration of the data from the sample using the 2013 INTCAL program and the INTCAL13 database (Reimer and others, 2013), following the approach of Talma and Vogel (1993), yields an 80 percent (within two standard deviations, $2 \sigma$ ) chance of the lava erupting in the 1625-1892 date range (table 1). Although this does not provide strong evidence that the Black Cone eruption took place after 1790, it does indicate that it could well have taken place close to that time. The fact that the Black Cone lava is much darker, less weathered, and much less vegetated than the underlying prehistoric pāhoehoe reinforces this conclusion, as does the relative lack of wind-drift ash from summit eruptions on its surface. 
Table 1. Conventional radiocarbon age and eruption occurrence interval for the lower Keala'alea flow and for pāhoehoe underlying the Black Cone flow of Kīlauea Volcano, Island of Hawai'i.

[ID, identification; ${ }^{14} \mathrm{C}$, carbon-14; $\delta^{13} \mathrm{C}$, measure of the ratio of carbon-13 and carbon-12 in parts per thousand; B.P., before present (present=A.D. 1950); $2 \sigma$, two standard deviations; yr, year; \%, percent; AMS, accelerator mass spectrometry; NA, not applicable]

\begin{tabular}{|c|c|c|c|c|c|c|c|}
\hline Laboratory & Laboratory ID ${ }^{1}$ & Sample ID & $\begin{array}{l}{ }^{14} \mathrm{C} \text { age, } y r \\
\text { B.P. }\end{array}$ & $\begin{array}{c}2 \sigma \text { calibrated date } \\
\text { interval }\end{array}$ & $\begin{array}{l}\text { Probability of eruption } \\
\text { in this interval }\end{array}$ & Type of analysis & $\delta^{13} \mathrm{C}$ \\
\hline $\begin{array}{l}\text { Beta Analytics, Inc., } \\
\text { Miami, Florida }\end{array}$ & Beta-457297 & PuuKou01 & $170 \pm 30$ & $1722-1817$ & $55 \%$ & AMS & -24.5 \\
\hline $\begin{array}{l}\text { U.S. Geological Survey, } \\
\text { Reston, Virginia }\end{array}$ & W3938 & $\mathrm{NA}^{2}$ & $210 \pm 60^{3}$ & $1625-1892$ & $80 \%$ & AMS & NA \\
\hline
\end{tabular}

'Sample locations (latitude, longitude (World Geodetic System 1984)) and descriptions:

Beta-457297-19.29429, -155.39075 (charcoal beneath edge of flow near vent, lower Keala'alea flow).

W3938 - 19.2564, -155.4078 (charcoal in tree mold, flow underlying Black Cone flow).

${ }^{2}$ Collected by Holcomb (1981).

${ }^{3}$ From Holcomb (1981) and Rubin and others (1987).
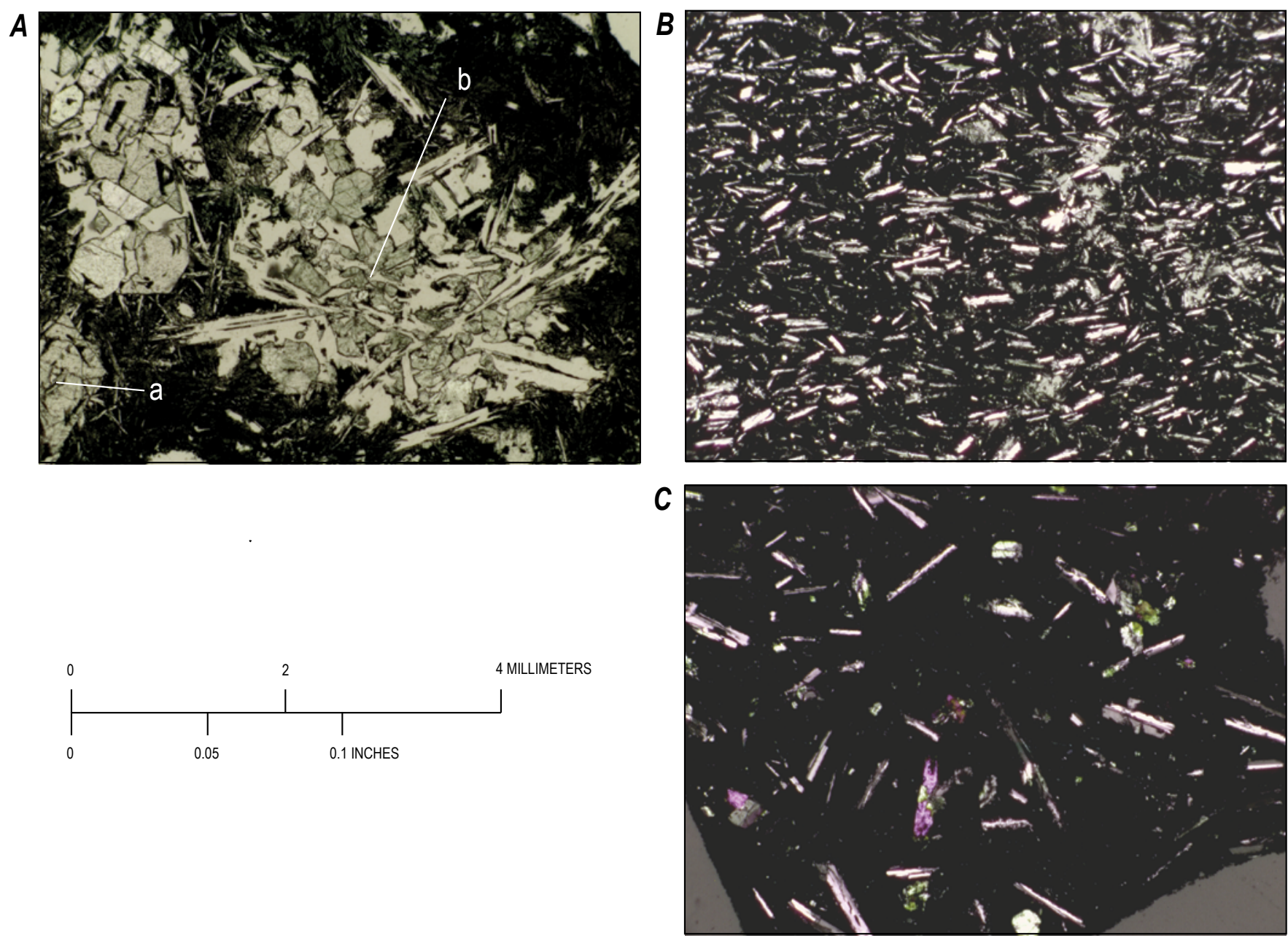

Figure 4. Photomicrographs of thin-sectioned samples from the lower Keala'alea and Black Cone lava flows and the Kamakai'a Lava Flow of Killauea Volcano, Island of Hawai'i. A, lower Keala'alea flow-numerous subhedral to euhedral olivine grains. Some larger crystals show zonally controlled skeletal or hopper forms (a). Most feldspar and olivine grains occur in aggregates with loosely radiating structures separated by dark groundmass (b). Aggregates typically show evidence of having partially broken apart. The sizes and abundance of crystals increase in samples downrift. $B$, Kamakai'a Lava Flow-very sparse olivine crystals present; dominantly plagioclase microlites, which form a loosely flow-lineated fabric in places. Opaque-oxide rich ground mass. C, Black Cone flow-contains scattered angular, subhedral grains of olivine and plagioclase microlites, more widely spaced than those seen in the two flows described above. Crystals are randomly scattered in most places, although faint flow lineation is evident in patches. (Photographs by Richard Hazlett.) 
Table 2. Selected geochemical analyses of lava flows examined for this study in the Southwest Rift Zone of Kīlauea Volcano, Island of Hawaiii.

[All samples, except S12-58, were collected by the authors. Major element oxides are normalized weight percentages on a volatile-free basis with total iron expressed as FeO. Trace elements are in parts per million. UK, upper Keala'alea flow; LK, lower Keala'alea flow; O, "outlier" samples petrographically similar to Keala'alea lava; K, Kamakai'a Lava Flow; BC, Black Cone flow. All analyses done at the University of Massachusetts, Amherst, Ronald B. Gilmore X-Ray Fluorescence Laboratory (http://www.geo.umass.edu/xrf/index.htm). Footnote at bottom of table gives specific sample locations. km, kilometer; m, meter]

\begin{tabular}{|c|c|c|c|c|c|c|c|c|c|c|c|c|}
\hline \multirow[b]{2}{*}{$\begin{array}{l}\text { Oxide or } \\
\text { element }\end{array}$} & \multicolumn{12}{|c|}{ Sample number and flow ${ }^{1}$} \\
\hline & $\begin{array}{c}\text { RH16-12 } \\
\text { UK }\end{array}$ & $\begin{array}{c}\text { RH16-13 } \\
\text { UK }\end{array}$ & $\begin{array}{c}\text { RH16-34 } \\
\text { UK }\end{array}$ & $\begin{array}{c}\text { RH16-03 } \\
\text { LK }\end{array}$ & $\begin{array}{c}\text { RH16-14 } \\
\text { LK }\end{array}$ & $\begin{array}{c}\text { RH16-16 } \\
\text { LK }\end{array}$ & $\begin{array}{c}\text { RH16-39 } \\
0\end{array}$ & $\begin{array}{c}S 12-58 \\
0\end{array}$ & $\begin{array}{c}\text { RH16-09 } \\
\text { K }\end{array}$ & $\begin{array}{c}\text { RH16-23 } \\
\text { K }\end{array}$ & $\begin{array}{c}\text { RH16-05 } \\
\text { K }\end{array}$ & $\begin{array}{c}\text { RH16-15 } \\
\text { BC }\end{array}$ \\
\hline $\mathrm{SiO}_{2}$ & 51.62 & 51.40 & 51.52 & 51.38 & 51.03 & 51.07 & 51.41 & 51.56 & 53.65 & 54.78 & 54.32 & 52.05 \\
\hline $\mathrm{TiO}_{2}$ & 2.44 & 2.42 & 2.46 & 2.44 & 2.37 & 2.38 & 2.48 & 2.46 & 3.55 & 3.20 & 3.2 & 3.31 \\
\hline $\mathrm{MnO}$ & 0.18 & 0.18 & 0.18 & 0.18 & 0.18 & 0.18 & 0.176 & 0.174 & 0.19 & 0.19 & 0.19 & 0.19 \\
\hline $\mathrm{MgO}$ & 7.24 & 7.63 & 7.33 & 8.08 & 8.80 & 8.65 & 8.97 & 8.80 & 4.12 & 3.86 & 3.90 & 5.73 \\
\hline $\mathrm{CaO}$ & 10.93 & 10.90 & 10.91 & 10.71 & 10.40 & 10.53 & 10.79 & 10.48 & 7.92 & 7.53 & 7.60 & 9.49 \\
\hline $\mathrm{Na}_{2} \mathrm{O}$ & 2.26 & 2.16 & 2.25 & 2.21 & 2.16 & 2.09 & 2.24 & 2.16 & 3.25 & 3.26 & 3.44 & 2.66 \\
\hline \multicolumn{13}{|c|}{ Trace elements } \\
\hline $\mathrm{Nb}$ & 12.8 & 12.8 & 12.8 & 12.7 & 12.8 & 12.6 & 13.1 & 11.9 & 30.0 & 32.2 & 31.4 & 20.3 \\
\hline $\mathrm{Zr}$ & 153 & 153 & 155 & 149 & 151 & 148 & 140 & 142 & 375 & 402 & 396 & 238 \\
\hline $\mathrm{Y}$ & 24.7 & 24.6 & 24.8 & 24.3 & 24.6 & 23.8 & 25 & 25 & 49.0 & 52.0 & 51.5 & 34.8 \\
\hline $\mathrm{Sr}$ & 316 & 311 & 317 & 316 & 303 & 299 & 308 & 310 & 360 & 361 & 360 & 350 \\
\hline $\mathrm{U}$ & 0 & 0 & 0 & 0 & 0 & 0 & 3 & 1 & 0 & 0 & 0 & 0 \\
\hline $\mathrm{Rb}$ & 6.7 & 6.5 & 6.8 & 6.4 & 6.7 & 6.7 & 8 & 8 & 20.4 & 22.0 & 21.7 & 11.8 \\
\hline $\mathrm{Th}$ & 1 & 2 & 1 & 1 & 1 & 1 & 1 & 1 & 3 & 3 & 3 & 2 \\
\hline $\mathrm{P}$ & 0 & 1 & 1 & 1 & 1 & 1 & 1 & 2 & 2 & 2 & 3 & 2 \\
\hline $\mathrm{Ce}$ & 31 & 31 & 29 & 28 & 31 & 29 & 28 & 27 & 74 & 81 & 79 & 46 \\
\hline $\mathrm{Ba}$ & 89 & 93 & 96 & 89 & 90 & 88 & 105 & 109 & 226 & 249 & 240 & 147 \\
\hline $\mathrm{La}$ & 7 & 7 & 6 & 5 & 9 & 7 & 12 & 11 & 24 & 28 & 28 & 12 \\
\hline
\end{tabular}

'Sample locations (latitude, longitude (World Geodetic System 1984)) and descriptions:

RH16-12 - 19.33299, -155.35321 (lava from pond wall at east end of fissure, upper Keala'alea flow).

RH16-13 - 19.32863, -155.35826 (lava from pond wall at west end of fissure, upper Keala'alea flow).

RH16-34 - 19.31067, -155.37114 (pāhoehoe lava $2.2 \mathrm{~km}$ southwest of fissure, upper Keala'alea flow).

RH16-03-19.26095, -155.41198 (pāhoehoe lava $~ 3.4$ km southwest of fissure, lower Keala'alea flow).

RH16-14 - 19.24214, -155.39518 (lava from pond wall at southwest end of fissure, lower Keala'alea flow).

RH16-16 - 19.29743, -155.38987 (pāhoehoe lava on lava pad northeast of main body of lower Keala'alea flow).

RH16-39 - 19.34855, -155.32714 (pāhoehoe lava at base of small cone $\sim 1 \mathrm{~km}$ southeast of Pu'ukoa'e).

S12-58 - 19.34984, -155.27989 (tephra from central Koa'e fault system, provided by D.A. Swanson, U.S. Geological Survey).

RH16-09-19.30301, -155.36847 (lava from rootless shield $\sim 300$ m northeast of Kamakai'a cone, Kamakai‘a Lava).

RH16-23-19.30619, -155.36163 (toothpaste lava 100 m southeast of Kamakai‘a Waena, Kamakai‘a Lava Flow).

RH16-05-19.30586, -155.36577 (spatter from cone 200 m southwest of Kamakai'a Waena, Kamakai'a Lava Flow).

RH16-15-19.24710, -155.41246 (lava from channel wall 30 m south of fissure, Black Cone flow). 


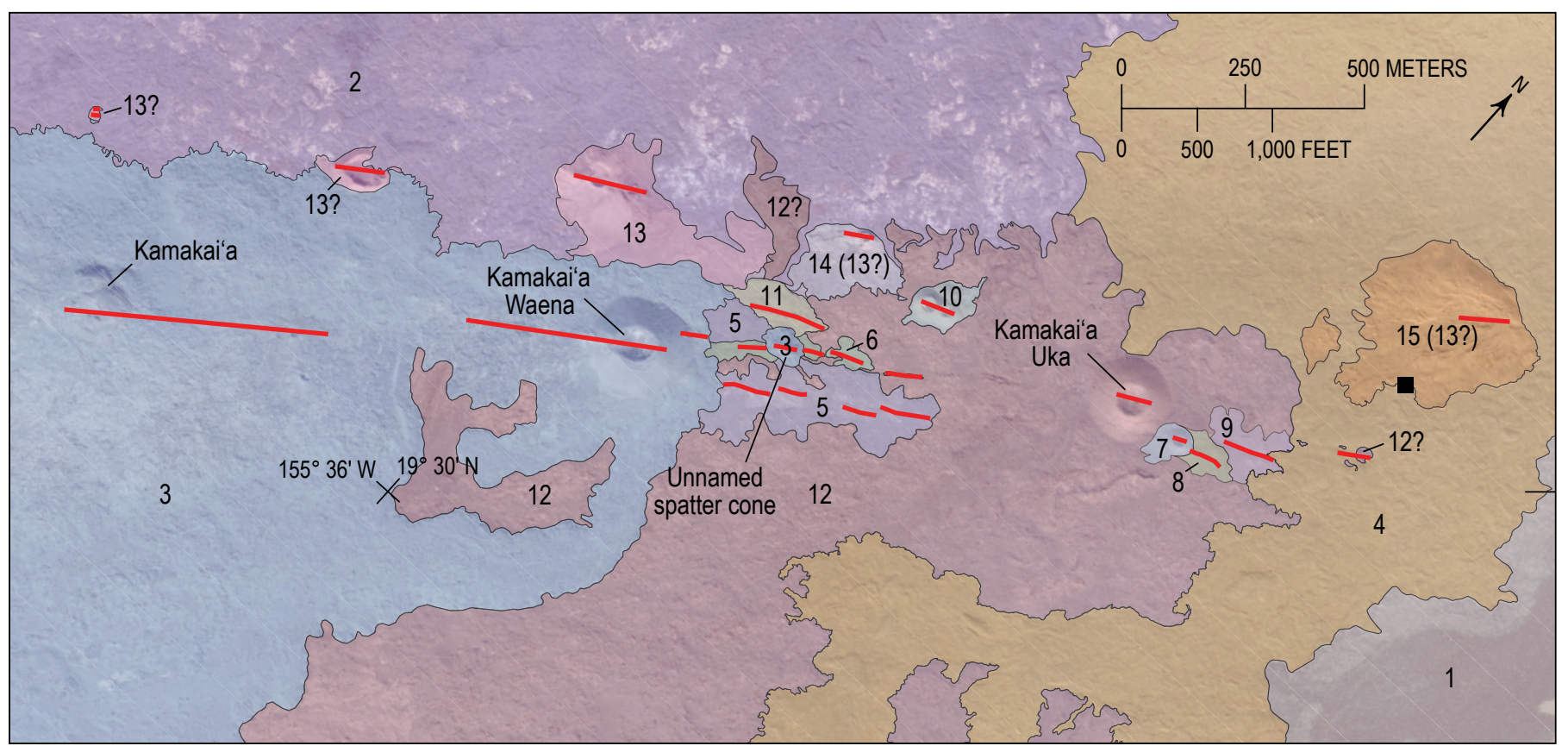

Base image @ 2015 DigitalGlobe NextView License

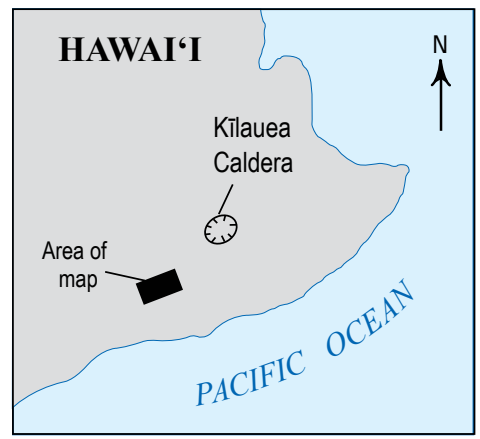

\begin{tabular}{|c|c|}
\hline 1 & 1974 flow \\
\hline 2 & 1920 flow \\
\hline 3 & Kamakai'a Lava Flow \\
\hline 4 & Upper Keala'alea flow \\
\hline 5 & Post-1790 eruption \\
\hline 6 & Post-1790 eruption \\
\hline
\end{tabular}

\section{EXPLANATION}

Figure 5. Geologic map of the central and eastern Kamakai'a Hills of Kïlauea Volcano, Island of Hawai'i. The Kamakai'a Hills are a group of cinder and spatter cones with three main cones-Kamakai'a, Kamakai'a Waena, and Kamakai'a Uka. See text for discussion. The relative chronological order among eruptions of similar age, where not in contact, is unknown.

Several additional small outbreaks not mapped by Holcomb (1987) or Wolfe and Morris (1996) also show evidence of post-1790 eruption. Four of these outbreaks (fig. 5, map units 5, 6, 8, and 9), which overlie 1790 accretionary-lapilli-bearing ash, erupted from small (less than $3 \mathrm{~m}$ high), short (less than several hundred meters long) spatter ramparts in the Kamakai'a Hills. A small (less than $10 \mathrm{~m}$ high) spatter cone immediately upslope from the Kamakai'a Uka cone (fig. 5, map unit 7) also postdates 1790. Stratigraphic relations show that at least two of these eruptions (fig. 5, map units 5 and 6) preceded emplacement of the Kamakai'a Lava Flow or were part of an earlier phase of that eruption, and one of these eruptions (fig. 5, map unit 9) predates the upper Keala'alea flow (fig. 5, map unit 4).
In addition, a very small cone and pāhoehoe flow ( 0.85 hectare) located $0.8 \mathrm{~km}$ southwest of Pu'ukoa'e in the upper Southwest Rift Zone (unit "khu" of Neal and Lockwood, 2003) bears a La/ $\mathrm{Yb}$ composition indicating extrusion roughly around the same time as the Keala'alea flows (Pietruska and Garcia, 1999; Swanson and others, 2018). Absence of 1790 accretionary-lapilli-bearing ash, widespread on adjacent older flow surfaces, is a telling indicator of the relative recentness of this very small outbreak of lava, which lies approximately along north-eastward extension of the upper Keala'alea eruptive fissure. Indeed, close similarity in the petrography and geochemistry of this lava, the Keala'alea flows, and the spatter of a tiny outbreak in the nearby Koa'e fault system (Swanson and others, 2018), indicate that each of these scattered occurrences may be products of the same widespread, early 19th-century eruption (table 2). 


\section{Significance of Late 18th- to Early 19th-Century Eruptions in the Southwest Rift Zone}

The set of previously undocumented late 18 th- to early 19th-century eruptions in the Southwest Rift Zone adds to the list of volcanic events that took place during the change in overall behavior of Kîlauea as it transitioned from three centuries of dominantly explosive volcanic activity to the effusive period characteristic of the present (Swanson and others, 2014, 2017; Wright and Klein, 2014). Large Southwest Rift Zone flank eruptions could have drained Kîlauea's magma reservoir sufficiently to induce explosive activity within the caldera, accounting for at least some of the seven post-1790 to pre-1823 tephra layers mapped around the summit (Biass and others, 2018; Swanson and Houghton, 2018). Except for an observation made by the 1794 Vancouver Expedition of a possible eruptive plume in the central East Rift Zone (Vancouver, 1798), no evidence exists that any subaerial part of the East Rift Zone was active during this same interval.

Multiple outbreaks of lava in the Kamakai'a Hills between 1790-1823 underscore that this concentrated vent area has formed through many eruptions over a long span of time (fig. 5). Presuming that the bend in the Southwest Rift Zone near Pu'ukou (fig. 1) acts as a location for intruding magma to stall and accumulate within the rift zone (Holcomb, 1987), the complexity of volcanic features in the Kamakai'a Hills indicate that the bend has been a persistent feature in the rift zone's development. The evolved, relatively high-silica chemistry of the Kamakai'a flow (table 2) is consistent with the idea of magma storage and fractionation. A potentially significant and unresolved issue for understanding volcanism in the Southwest Rift Zone is whether magma (1) backs up from the bend near Pu'ukou, as Holcomb (1987) suggested might happen, (2) intrudes in a largely passive way from the summit magma reservoir directly southwestward along Koa'e fault system structures, or (3) originates from some deeper, directly underlying source to erupt in the Kamakai'a Hills. Likewise, the possible relation of the Kamakai'a branch of the Southwest Rift Zone to the 1823 eruption described by Ellis, or to other future outbreaks in the lower part of the rift zone, remains unclear.

\section{Conclusions}

Kîlauea's Southwest Rift Zone was more volcanically active in the late 18th- to early 19th-centurys than previously assumed. Stratigraphy and radiocarbon dating indicate that two large, long-lasting eruptions of lava - the Keala'alea lava flow and the Kamakai'a Lava Flow - took place sometime in the interval 1790-1823. The Kamakai'a eruption was accompanied by cone-building explosive activity. The Keala'alea eruption, the more widespread of the two eruptions, broke out in at least two and possibly four places, including very short-lived extrusions of spatter and lava near $\mathrm{Pu}$ 'ukoa'e and in the Koa'e fault system. A series of minor eruptions, some possibly related to the Kamakai'a Lava Flow, also broke out in the central and eastern Kamakai'a Hills during this same period. The Black Cone flow, southwest of the Keala'alea lava flow and the Kamakai'a Lava Flows, may have also erupted during this interval.

\section{References Cited}

Baldwin, E.D., and Wright, G.F., 1907, Kapapala-Kau, Hawaii: Hawaii Territory Survey, Registered Map No. 2388, 1 sheet, scale 1:24,000. [Also available online at http://ags. hawaii.gov/survey/map-search/ (registered map no. 2388).]

Biass, S., Swanson, D.A., and Houghton, B.F., 2018, New perspective on the nineteenth-century golden pumice deposit of Kīlauea Volcano, in Poland, M.P., Garcia, M.O., Camp, V.E., Grunder, A., eds., Field volcanology-A tribute to the distinguished career of Don Swanson: Geological Society of America Special Paper 538, p. 227-246.

Clague, D.A., Hon, K.A., Anderson, J.L., Chadwick, W.W., and Fox, C.G., 1994, Bathymetry of the Puna Ridge, Kilauea Volcano, Hawaii: U.S. Geological Survey Miscellaneous Field Map Series Map MF-2237, 1 sheet, scale 1:150,000. [Also available at https://pubs.er.usgs.gov/ publication/mf2237.]

Dana, J.D., 1849, Geology, U.S. Exploring Expedition, during the years $1838,1839,1840,1841,1842$, under the command of Charles Wilkes, U.S.N.: Philadelphia, C. Sherman, v. 10, p. 713.

Donn, J.M., 1901, Hawaii-Hawaiian Islands: Hawaii Territory Survey, 1 sheet, scale 1:120,000. [Also available at http://ags.hawaii.gov/survey/map-search/ (registered map no. 2060).]

Dutton, C.E., 1884, Hawaiian volcanoes: U.S. Geological Survey 4th Annual Report, p. 75-219.

Ellis, W., 1825, A journal of a tour around the Island of Hawaii, the Largest of the Sandwich Islands: New York, Boston, Crocker and Brewster Publishing, 264 p.

Hitchcock, C.H., 1911, Hawaii and its volcanoes: Honolulu, The Hawaii Gazette Co., Ltd., 314 p.

Holcomb, R.T., 1981, Kilauea Volcano, Hawaii-chronology and morphology of the surficial lava flows: U.S. Geological Survey Open-File Report 81-354, 335 p. [Also available at https://pubs.er.usgs.gov/publication/ofr81354.] 
Holcomb, R.T., 1987, Eruptive history and long-term behavior of Kilauea Volcano, in R.W. Decker, Wright, T.L., and Stauffer, P.H., Volcanism in Hawaii: U.S. Geological Survey Professional Paper 1350, p. 261-350. [Also available at https://pubs.usgs.gov/pp/1987/1350/.]

Lipman, P.W., Sisson, T.W., Coombs, M.L., Calvert, A., and Kimura, J.-I., 2006, Piggyback tectonics-Long-term growth of Kilauea on the south flank of Mauna Loa: Journal of Volcanology and Geothermal Research, v. 151, no. 103, p. 73-108.

Lockwood, J.P., and Lipman, P.W., 1980, Recovery of datable charcoal beneath young lavas-Lessons from Hawaii: Bulletin Volcanologique, v. 43, no. 3, p. 609-615.

Neal, C.A., and Lockwood, J.P., 2003, Geologic map of the summit region of Kilauea Volcano: U.S. Geological Survey Geologic Investigation Series Map I-2759, 1 sheet and pamphlet, scale 1:24,000. [Also available at https://pubs. usgs.gov/imap/i2759/.]

Patrick, M.P., and Orr, T.R., 2011, Rootless shield and perched lava pond collapses at Kīlauea Volcano, Hawai' $i$ : Bulletin of Volcanology, v. 74, no. 1, p. 67-78.

Pietruszka, A.P., and Garcia, M.O., 1999, A rapid fluctuation in the mantle source and melting history of Kilauea Volcano inferred from the geochemistry of its historical summit lavas; Journal of Petrology, v. 40, p. 1321-1342.

Reimer, P.J., Baillie, M.G., Bard, E., Bayliss, A., Beck, J.W., Paul G Blackwell, P.D., Ramsey, C.B., Buck, C.E., Cheng, H., Lawrence Edwards, R.L., Friedrich, M., Grootes, P.M., Guilderson, T.P., Haflidason, H., Hajdas, I., Hatté, C., Heaton, T.J., Hoffmann, D.L., Hogg, A.G., Hughen, K.A., Kaiser, K.F., Kromer, B., Manning, S.W., Niu, M., Reimer, R.W., Richards, D.A., Scott, E.M., Southon, J.R., Staff, R.A., Turney, C.S.M., and van der Plicht, J., 2013, IntCal13 and marine 13 radiocarbon age calibration curves $0-50,000$ years cal BP: Radiocarbon Journal v. 55, no. 4, p. 1869-1887.

Rubin, M., Gargulinski, L.K., and McGeehin, J.P., 1987, Hawaiian radiocarbon dates, in Decker, R.W., Wright, T.L., and Stauffer, P.H., Volcanism in Hawaii: U.S. Geological Survey Professional Paper 1350, v. 1, p. 213-242. [Also available at https://pubs.usgs.gov/ $\mathrm{pp} / 1987 / 1350 /$.

Simkin, T., and Siebert, L., 1994, Volcanoes of the World, 2nd ed.: Smithsonian Institution, 349 p.

Stearns, H.T., 1926, The Keaiwa of 1823 lava flow from Kilauea Volcano, Hawaii: Journal of Geology, v. 54, no. 4, p. 336-351.
Stearns, H.T., Clark, W.O., and Meinzer, O.E., 1930, Geology and water resources of the Kau district, Hawaii (including parts of Kilauea and Mauna Loa Volcanoes), with a chapter on ground water in the Hawaiian Islands: U.S. Geological Survey Water Supply Paper 616, 194 p., 33 plates, https:// doi.org/10.3133/wsp616.

Swanson, D., and Houghton, B.F., 2018, Products, processes, and implications of Keanakako'i volcanism, Kīlauea Volcano, Hawai'i, in Poland, M.P., Garcia, M.O., Camp, V.E., Grunder, A., eds., Field volcanology -A tribute to the distinguished career of Don Swanson: Geological Society of America Special Paper 538, p. 159-190.

Swanson, D., Biass, S., and Garcia, M.O., 2017, End of an era-The final explosive eruptions of Keanakāko' $i$ tephra at Kīlauea [abs.]: Geological Society of America Cordilleran Section, 113th annual meeting, Abstracts with Programs, v. 49, no. 4., https://doi.org/10.1130/abs/2017CD-292369.

Swanson, D., Fiske, R.S., Thornber, C.R., and Poland, M.P., 2018, Dikes in the Koa'e fault system, and the Koa'e-east rift zone structural grain at Kîlauea Volcano, Hawai'i, in Poland, M.P., Garcia, M.O., Camp, V.E., and Grunder, A., eds., Field volcanology-A tribute to the distinguished career of Don Swanson: Geological Society of America Special Paper 538, p. 247-274.

Swanson, D., Rose, T.R., Mucek, A.E., Garcia, M.O., Fiske, R.S., and Mastin, L.G., 2014, Cycles of explosive and effusive eruptions of Kīlauea Volcano, Hawai' $\mathrm{i}$ : Geology, v. 42 , no. 7 , p. 631-634.

Swanson, D.A., Rose, T.R., Fiske, R.S., and McGeehin, J.P., 2012, Keanakāko'i Tephra produced by 300 years of explosive eruptions following collapse of Kīlauea's caldera in about $1500 \mathrm{CE}$ : Journal of Volcanology and Geothermal Research, v. 215-216, p. 8-25.

Talma, A.S., and Vogel, J.C., 1993, A simplified approach to calibration C14 dates: Radiocarbon Journal, v. 35, p. 317-322.

U.S. Geological Survey, 1921, Kilauea, U.S. Geological Survey topographic quadrangle maps, 1 sheet, scale $1: 62,500$.

U.S. Geological Survey, 1923, Pahala, U.S. Geological Survey topographic quadrangle maps, 1 sheet, scale 1:62,500.

U.S. Geological Survey, 1981a, Kau Desert, Hawaii: U.S. Geological Survey topographic quadrangle map, 1 sheet, scale 1:24,000.

U.S. Geological Survey, 1981b, Wood Valley, Hawaii: U.S. Geological Survey topographic quadrangle map, 1 sheet, scale $1: 24,000$. 
Vancouver, G., 1798, A voyage of discovery to the North Pacific Ocean, and round the world: London, G.G. Robinson, J. Robinson, J. Edwards Publishing, 3 vols.

Walker, G.W., 1969, Geologic map of the Kau Desert Quadrangle, U.S. Geological Survey Map GQ-827, 1 sheet, scale 1:24,000. [Also available at https://pubs.er.usgs.gov/publication/gq827.]

Wolfe, E.A., and Morris, J., compilers, 1996, Geologic map of the Island of Hawaii: U.S. Geological Survey Miscellaneous Investigations Series Map I-2524-A, 3 sheets, scale 1:100,000. [Also available at https://pubs.usgs.gov/imap/2524a/.]
Wright, T.L., and Klein, F.W., 2014, Two hundred years of magma transport and storage at Kîlauea Volcano, Hawai' $i$, 1790-2008: U.S. Geological Survey Professional Paper 1806, 240 p., 9 appendixes, https://dx.doi.org/10.3133/ pp1806.

Wright, T.L., and Takahashi, J.T., 1989, Observations and Interpretation of Hawaiian volcanism and seismicity, 1779-1995-An annotated bibliography and subject index: University of Hawaii Press, 270 p. 


\section{Appendix-Overview of Field Studies and Changes in the Mapping of Kïlauea's Southwest Rift Zone}

An analysis of oral and written testimony from the early 18 th century indicates that pieces are missing from the historical record of Killauea's eruptions, particularly in the Southwest Rift Zone. For example, the native Hawaiians questioned by William Ellis in 1823 claimed that no "great explosion" of Kỉlauea had occurred since 1790, although these long-term residents also added that many coastal localities had been "overflowed" with lava since then (Ellis, 1825). In 1794, British Navy Captain George Vancouver, sailing along the coast of the Puna District, observed columns of "smoke" issuing from the central East Rift Zone, which accompanying Hawaiians related to an ongoing eruptionmotivation for them to make offerings to the goddess Pele (Vancouver, 1798). However vague and even contradictory these early accounts appear to be, they at least suggest that substantial, undocumented extrusions of lava from the rift zones took place in the decades immediately following 1790 .

Few geological investigations in the Southwest Rift Zone took place between the visit of the Ellis party in 1823 and the Maunaiki eruption nearly a century later (1919-1920), although numerous written accounts describe conditions and activity at the summit (for example, Dana, 1849; Dutton, 1884). Notably, the small 1868 Southwest Rift Zone eruption (Lava Flow of 1868) drew the immediate attentions of the missionary Titus Coan and the surveyor E.D. Baldwin, who visited the fissures and flow pads in the Southwest Rift Zone shortly after their development, leaving detailed correspondence later published by Hitchcock (1911).

Territorial surveyors completed a map of the Island of Hawai' $i$ in 1901 (Donn, 1901) that included a rough outline of the 1823 flow that so impressed Ellis. However, they extended this flow to include an 'a'a flow erupted from the nearby Cone Peak (Holcomb, 1987) and the 500-year-old Ke'āmuku Lava Flow from Mauna Loa's northeast rift zone - a rough error probably arising from too rapid a reconnaissance (fig. 6 ) because these flows were clearly erupted from different sources.

Confusion about Southwest Rift Zone geology in the early 20th century was further sown when Baldwin (Baldwin and Wright, 1907) more closely surveyed the rift zone, crudely mapping the contacts of the 1823 and 1868 flows as he understood them. Although Baldwin, as mentioned above, had observed and measured the modest flow pads erupted in 1868 , his estimate of what this eruption produced greatly increased by the time he completed his survey, as he also assigned the 1868 date to lava erupted in 1823. Although avoiding the conflation error of Donn (1901), the Baldwin designation of historically erupted flows in the rift zone also later proved to be incorrect (fig. 6). Dartmouth College geologist C.E. Hitchcock nonetheless accepted Baldwin's interpretations about which flows had erupted in 1823 and 1868, without question, as he explored the rift zone a few years later in preparation for publishing a textbook on Hawaiian volcanism (Hitchcock, 1911).
Hitchcock stated that "The first source of the 1823 flow was three miles above these [the Kamakai'a] hills, from a long fissure, and it seems to have broken out again, in its line of flow at these hills, forming the two larger cones" (Hitchcock, 1911, p. 169-170). In other words, he identified the upper Keala 'alea flow, shown in figures 1 and 5, as the initial outbreak of the 1823 eruption, then stated that the locus of activity during this eruption had jumped south $2 \mathrm{~km}$ to the Kamakai'a Hills. It isn't entirely clear which two cones in the Kamakai'a group he refers to with this comment; but certainly, the Kamakai'a Waena cone is one, and the Kamakai'a Uka cone is likely the other, both being smooth sided, nearly symmetrical, and the two largest cones in the set (fig. 5). Hitchcock continues:

Near the large cone [Kamakai'a Waena] are two ancient cones, surrounded by the new lava, one of these was completely spattered and plastered over by ejections from the large cone; it was on this cone, while riding along its base, that my horse broke through the crust, and while floundering around for a footing brought up large quantities of yellow tufa ... of a beautiful yellow ochre color. On investigation I found that a large portion of this cone was composed of the same material. (Hitchcock, 1911, p. 169-170)

This same cone, no doubt, is the older, northwestern neighbor of Kamakai'a Waena (fig. 5). Hitchcock (1911) also believed that the lower Keala 'alea flow several kilometers to the west (fig. 1) erupted in 1823 too, based on the "youthful appearance" of this lava.

Fifteen years later, Stearns (1926) demonstrated that Baldwin had erroneously attributed the Keaîwa Lava Flow of 1823 to the Lava Flow of 1868, while assigning the large flow originating in the western Kamakai'a Hills (the Kamo'oali' $i$ Lava Flow on later USGS topographic quadrangle maps) to the 1823 outbreak instead (fig. 6). Baldwin appears to have made this mistake based on the testimony of Judge F.S. Lyman, who was living in the lower Ka' $\bar{u}$ District and reported seeing glowing sky in the direction of the Great Crack during the 1868 eruption, although landscape features such as the Pu'unāhāhā scarp blocked direct viewing, and Lyman's sense of direction could well have been confused. Baldwin was also aware of Ellis's account of the lava in 1823 entering the ocean and presumed that the Kamo'oali'i Lava Flow did so too-a surveying lapse that Stearns easily corrected by showing that the latter flow does not, in fact, reach the sea. Therefore, the "youthful" flows Hitchcock associated with the Kamakai'a Hills, and which Baldwin thought, at least in part, must have erupted in 1823 too, were older; and very likely prehistoric for all anyone knew at the time.

Walker (1969) and Neal and Lockwood (2003) published U.S. Geological Survey geological quadrangle maps in the central 

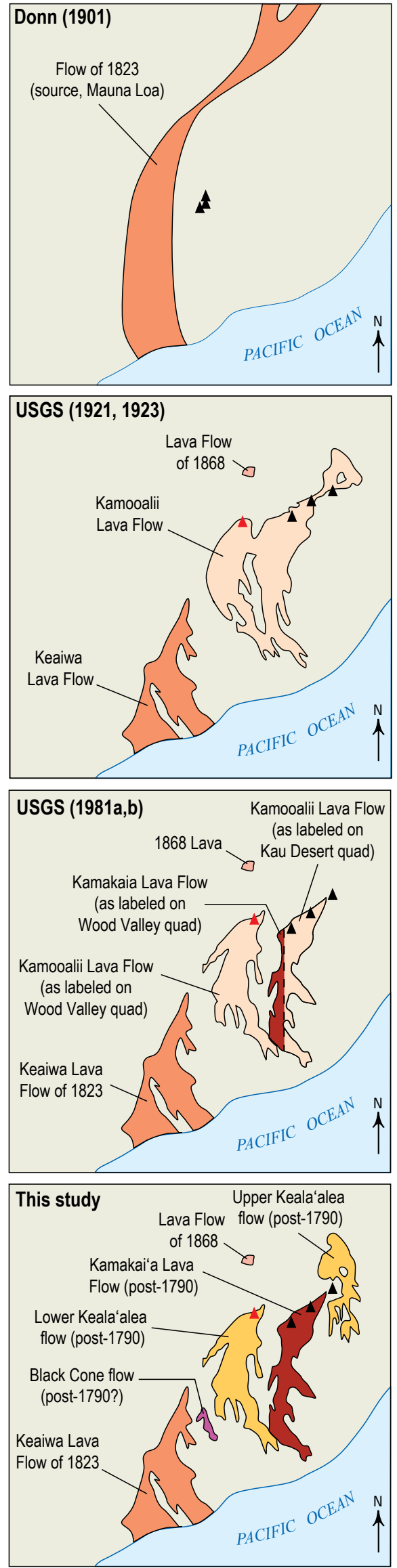
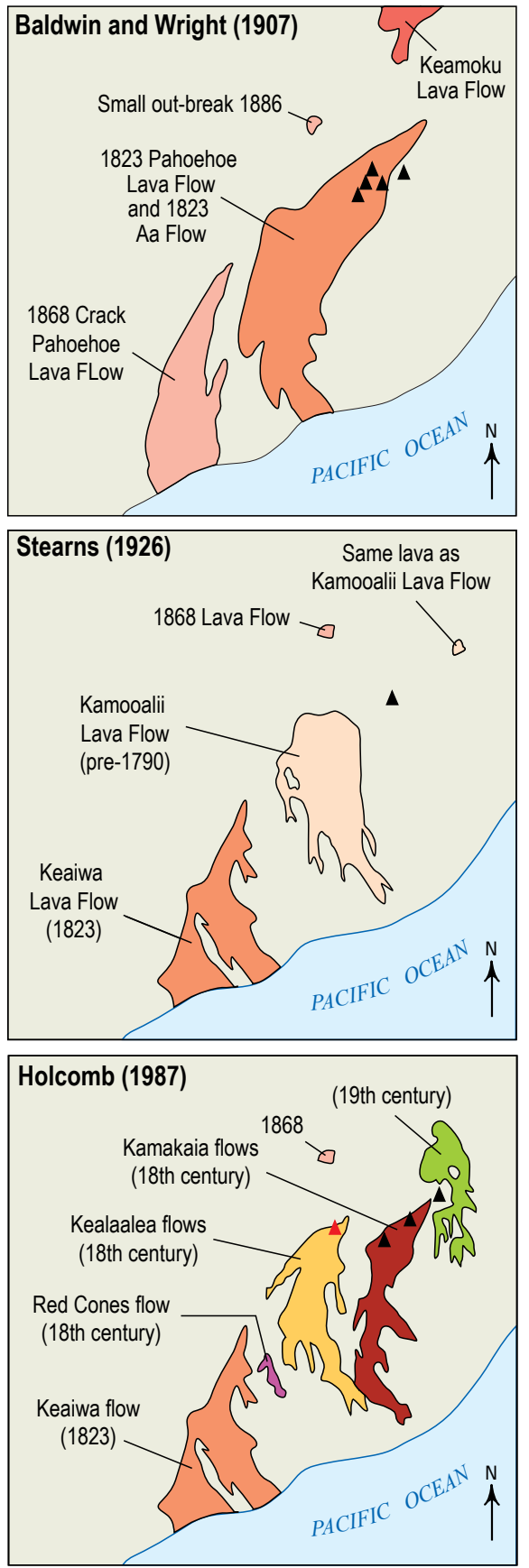

Figure 6. Significant changes in the published mapping and names of young Southwest Rift Zone (SWRZ) lava flows of Kilauea Volcano, Island of Hawai'i, examined in this study, from early 20th century to present. Note that place names shown are the spellings used in the cited references. USGS, U.S. Geological Survey; ERZ, East Rift Zone. 
and upper Southwest Rift Zone. Walker concluded then that the Kamo'oali'i Lava Flow predated the 1790 eruption, claiming that patches of Keanakako'i Ash Member of the Puna Basalt (Swanson and others, 2012, proposed that the name be changed to the Keanakako'i Tephra, which is now generally most used), including the 1790 accretionary-lapilli-bearing ash (unit I), overlie this lava. Our work demonstrates that this is not the case. Walker possibly mistook well-layered weathered clays deposited from frequent dust storms in the upper Southwest Rift Zone for in situ 1790 tephra. Neal and Lockwood did not map as far downrift as the Kamakai'a Hills.

Holcomb (1987) remapped the Southwest Rift Zone as part of his much larger study on the eruptive history of Kīlauea, combining ${ }^{14} \mathrm{C}$ dating with paleomagnetic measurements to categorize flows according to their age ranges (fig. 6). He also changed the nomenclature of flows in parts of the Southwest Rift Zone - to which we adhere as closely as we can in this study - designating the name Kealaalea flow (our Keala'alea flow) for the youthful appearing lava field centered around $\mathrm{Pu}$ 'ukou. This flow is called the Kamooalii Lava Flow on the Wood Valley, Hawaii, USGS topographic quadrangle map (U.S. Geological Survey, 1981b). Lava that erupted from the western Kamakai'a Hills is called the Kamakaia Lava Flow on the Wood Valley, Hawaii,
USGS topographic quadrangle map (U.S. Geological Survey, 1981b), whereas the same flow is labeled as the Kamo'oali' $i$ Lava Flow on the Kau Desert, Hawaii, USGS topographic quadrangle map (U.S. Geological Survey, 1981a). Holcomb (1987) called this the Kamakaia flow. We follow this usage but change it to Kamakai'a Lava Flow, to be consistent with the designation assigned by the U.S. Board on Geographic Names (https://geonames.usgs.gov/domestic/index.html).

Paleomagnetic data collected by Holcomb (1987) accurately indicated that the upper Keala'alea flow erupted sometime in the 19th century, at least consistent with Hitchcock's erroneous claim of an 1823 age for this flow (Hitchcock, 1911), although the error bars in his Holcomb's analysis are considerable ( \pm 60 years; table 1), and the secular variation curve for the regional magnetic field has since been refined. The lower Keala' alea lava flow, the Kamakai'a Lava Flow, lava flows from Pu'ukoa'e and the Cone Peak cinder cone, and an unnamed flow underlying the Black Cone flow each fell in his "18th century" age range, whereas all other Southwest Rift Zone lavas, excepting those erupted historically, he determined to be older - as much as 1,500 years (Holcomb, 1987). Holcomb's data were incorporated by the Big Island Mapping Project to generate a new geologic map of the Island of Hawai'i (Wolfe and Morris, 1996) that continues to be widely used.
Menlo Park Publishing Service Center, California

Manuscript approved for publication March 1, 2019

Edited by James W. Hendley II and Claire Landowski

Layout and design by Cory D. Hurd 
